\title{
Assessment of dynamic membrane filtration for biological treatment of old landfill
}

\section{leachate}

Mubbshir Saleem ${ }^{\mathrm{a}}$, Alessandro Spagni ${ }^{\mathrm{b} *}{ }^{\text {, Luca Alibardi }}{ }^{\mathrm{c}}$, Alberto Bertucco ${ }^{\mathrm{d}}$, Maria Cristina Lavagnolo $^{\mathrm{a}}$

${ }^{a}$ Department of Civil, Environmental and Architectural Engineering, University of Padova, via Marzolo 9, 35131 Padova, Italy

${ }^{\mathrm{b}}$ Laboratory of Technologies for Waste, Wastewater and Raw Materials Management, Italian National Agency for New Technologies, Energy and Sustainable Economic Development (ENEA), via M.M. Sole 4, 40129 Bologna, Italy

${ }^{c}$ Cranfield Water Science Institute, Cranfield University, Bedford, MK43 0AL, UK

${ }^{\mathrm{d}}$ Department of Industrial Engineering, University of Padova, via Marzolo 9, 35131 Padova, Italy

* Corresponding author:

Alessandro Spagni

ENEA, via M.M. Sole 4, 40129 Bologna, Italy

Email: alessandro.spagni@enea.it 


\begin{abstract}
This study investigated the behaviour of dynamic membrane (DM) filtration for the treatment of stabilised landfill leachate in a bench-scale pre-anoxic and aerobic submerged dynamic membrane bioreactor (DMBR). Four meshes with different openings $(10,52,85$ and $200 \mu \mathrm{m})$ were tested to support the development of DM. Differences were observed among the meshes in supporting the development of the cake layer constituting the DM. The treatment of landfill leachate had an impact on sludge characteristics resulting in deteriorated filtration performance of the DM. Effluent turbidity was often higher than 100 NTU for larger mesh pore size $(85$ and $200 \mu \mathrm{m})$. Low effluent turbidity was achieved with meshes with 10 and 52 $\mu \mathrm{m}\left(13 \pm 2\right.$ and $26 \pm 4 \mathrm{NTU}$, respectively) although at membrane fluxes lower than $10 \mathrm{~L} \mathrm{~m}^{-2} \mathrm{~h}^{-1}$. The bioreactor exhibited a moderate organics removal of 50-60\% and an ammonia oxidation between 80 and $90 \%$. Incomplete nitrification was observed due to increased concentrations of free ammonia and free nitrous acid, with nitrite effluent concentrations up to $1062 \mathrm{mgNO}_{2}^{-}$ $-\mathrm{N} \mathrm{L}^{-1}$. Due to the large presence of refractory organic matter in landfill leachate, denitrification was limited resulting in a total nitrogen removal of approximately $20 \%$.
\end{abstract}

Keywords: Dynamic membrane; fouling; landfill leachate; mesh filtration; nitrification; denitrification. 


\section{Introduction}

Sanitary landfill has been acknowledged as the most economically viable ultimate disposal option for municipal solid waste in most parts of the World, despite being placed at the bottom of waste management hierarchy (Fudala-Ksiazek et al., 2016). A major concern arising during landfill operation is the production of leachate resulting from the infiltration of water through the landfill body and the decomposing of waste. If not properly managed, leachate could severely contaminate groundwater sources, raising concerns regarding the protection of natural environment and public health (Renou et al., 2008).

Landfill leachate (LFL) treatment is challenging due to the high levels of contaminants including organics, ammonia, inorganic substances, heavy metals and toxic hydrocarbons (aromatic and phenolic compounds) together with the variability in its quantity and quality in both space and time (Kulikowska and Klimiuk, 2008; Renou et al., 2008). Moreover, the worldwide application of recent environmental legislation is changing the waste management chain reducing the disposal to landfills and, as a result, changing the leachate production and composition (Fudala-Ksiazek et al., 2016).

Biological processes have been proved to be effective in treating young leachates whereas their efficacy reduces with the increase of leachate age due to a shortage of biodegradable matter and an increase of refractory organics (Brennan et al., 2017; Mohammad-pajooh et al., 2017; Renou et al., 2008; Oloibi et al., 2017).

Membrane bioreactor (MBR), which consists in the integration of microfiltration or ultrafiltration (MF/UF) membranes with biological reactors, has gained much appreciation over the last decade and has been perceived as an advanced treatment process considering its excellent effluent quality and flexible operation (Judd, 2011). Studies on leachate treatment have demonstrated that MBRs are very effective under a wide range of loading conditions as compared to conventional biological treatment systems, particularly in treating LFL from old 
landfills (Alvarez-Vazquez et al., 2004; Hashisho and El-Fadel, 2016). However, the application of high loading conditions, long hydraulic retention time (HRT) and solids retention time (SRT) and the high concentrations of contaminants can increase membrane fouling (Ahmed and Lan, 2012). In addition, excessive amount of humic and fulvic acids usually present in LFL have shown to speed up membrane fouling (Sutzkover-Gutman et al., 2010). In a recent review on MBR application treating LFL, Hashisho and El-Fadel (2016) concluded that membrane fouling was the main bottleneck in the widespread application of MBR in leachate treatment due to its high fouling potential especially while treating stabilised LFL.

In this regard, dynamic membranes (DMs) could represent an innovative approach by purposefully exploiting fouling as a mean for solid liquid separation (Alibardi et al., 2014, 2016; Saleem et al., 2016; Xiong et al., 2016; Zhang et al., 2010). DM is defined as a selfforming and regenerative fouling surface that is formed by the deposition of suspended solids, colloids and microbial cell particles over a coarse underlying support material (Ersahin et al., 2012; Li et al., 2011; Liu et al., 2009).

Most of the studies on DM have been carried out on synthetic or real municipal wastewater under aerobic or anaerobic conditions and for anaerobic sludge digestion (Alibardi et al., 2014, 2016; Saleem et al., 2016; Ersahin et al., 2016; Jeison et al., 2008; Li et al., 2011; Liu et al., 2009; Kiso et al., 2000; Hu et al., 2016; Xiong et al., 2016; Zhang et al., 2010). Xie et al. (2014) studied the performances of an anaerobic dynamic MBR for the treatment of leachate by using a $40 \mu \mathrm{m}$ mesh as support material. Although these authors achieved solids retentions of the DM that were not comparable to those from MF/UF membranes, they reported a better effluent quality than conventional anaerobic treatment systems. To the best knowledge of the authors, no studies have yet evaluated the optimisation of organic matter and nitrogen removal for biological LFL treatment by using DMs. Similarly, the effect of the use of 
meshes with different pore sizes on the filtration performances of DMs treating LFL is also lacking.

This study aimed at evaluating the application of DMs in anoxic-aerobic process for the treatment of LFL from an old landfill. In particular, the effect of the use of different mesh sizes on the development of the DM was evaluated. The behaviour of developed DM was studied in conjunction with the effect of change in feed characteristics and operating conditions.

\section{Materials and methods}

\subsection{Experimental setup}

The study was conducted using a laboratory-scale, continuously mixed, anoxic-aerobic system (Fig. 1a). The experimental setup consisted of a pre-anoxic tank with a working volume of $2.8 \mathrm{~L}$ connected to an aerobic tank with a working volume of $7.5 \mathrm{~L}$. The tanks were made up of $5 \mathrm{~mm}$ thick Plexiglas cylinders. The internal diameter was $24 \mathrm{~cm}$ and $18 \mathrm{~cm}$ for aerobic and anoxic tanks, respectively, while depth was $30 \mathrm{~cm}$ for both tanks.

The filtration modules were constituted by a nylon mesh wounded over a cylindrical frame. The frame was a plastic body having an external diameter of $15 \mathrm{~mm}$ and a length of $70 \mathrm{~mm}$ with uniformly distributed openings of $5 \mathrm{~mm}$ X $3 \mathrm{~mm}$. The total surface area of the filtration module was $33 \mathrm{~cm}^{2}$ and approximately $61 \%$ (ca. $20 \mathrm{~cm}^{2}$ ) was the effective filtration area of each mesh. Three filtration modules were continuously immersed in the aerobic vessel and operated in parallel, resulting in a total effective filtration area of $60 \mathrm{~cm}^{2}$. Filtration flux were controlled through a three-line peristaltic pump (Watson Marlow SCI 400) which was connected to the three modules.

Four different meshes with pore sizes of 10, 52, 85 and $200 \mu \mathrm{m}$ were tested (Table 1). Meshes with porosities of 10,85 and $200 \mu \mathrm{m}$ were initially evaluated; however, due to changes in 
filtration behaviour of the sludge of the bioreactor, after 105 days of continuous operation the mesh with openings of $200 \mu \mathrm{m}$ was replaced with a new one of $52 \mu \mathrm{m}$ pore size.

The study was performed at ambient temperature $\left(21 \pm 1^{\circ} \mathrm{C}\right)$. Aeration of the aerobic tank was provided by a small air pump and diffusers. The air flow was controlled by using an air flowmeter (ColeParmer 1-800-323-4340). Leachate was fed to the anoxic tank through a peristaltic pump (Watson Marlow SCI 400) connected to a level sensor. Sludge recirculation flow was approximately four to five times the influent flow and was provided by means of a peristaltic pump (Watson Marlow SCI 400). The two bioreactors were kept completely mixed by using two overhead stirrers (LS F201A0151, VELP Scientifica). Solids retention time was maintained at 30-40 days.

\subsection{Inoculum and Feed}

Sludge collected from a full-scale municipal wastewater treatment plant (Padova, Italy) was used as inoculum. The sludge had a total suspended solids (TSS) concentration of $8.7 \mathrm{~g} \mathrm{~L}^{-1}$ and volatile suspended solids (VSS) of $5.4 \mathrm{~g} \mathrm{~L}^{-1}$.

The feed to the reactor consisted of raw LFL collected from an old ( $>25$ years) landfill site located in Veneto Region, Italy. The characteristics of the LFL samples are reported in Table 2. The LFL sample used for this study can be considered as stabilised and typical of old landfills (Kjeldsen et al., 2002). The leachate was collected approximately every month and stored at $4{ }^{\circ} \mathrm{C}$ before use. To ensure the availability of essential micronutrients to support biomass activity following micronutrients were added in the feed wastewater:

\footnotetext{
$\mathrm{Na}_{2} \mathrm{MoO}_{4} * 2 \mathrm{H}_{2} \mathrm{O}\left(0.22 \mathrm{mg} \mathrm{Mo} \mathrm{L}{ }^{-1}\right), \mathrm{ZnSO}_{4} * 7 \mathrm{H}_{2} \mathrm{O}\left(0.23 \mathrm{mg} \mathrm{Zn} \mathrm{L}{ }^{-1}\right), \mathrm{CuSO}_{4} * 5 \mathrm{H}_{2} \mathrm{O}(0.128 \mathrm{mg}$ $\left.\mathrm{Cu} \mathrm{L}^{-1}\right), \mathrm{NiCl}_{2} * 6 \mathrm{H}_{2} \mathrm{O}\left(0.1 \mathrm{mg} \mathrm{Ni} \mathrm{L}^{-1}\right), \mathrm{H}_{3} \mathrm{BO}_{4}\left(0.007 \mathrm{mg} \mathrm{B} \mathrm{L}^{-1}\right), \mathrm{Ne}_{2} \mathrm{SeO}_{3}\left(0.06 \mathrm{mg} \mathrm{Se} \mathrm{L}^{-1}\right)$, $\mathrm{MnCl}_{2} * 4 \mathrm{H}_{2} \mathrm{O}\left(0.56 \mathrm{mg} \mathrm{Mn} \mathrm{L}{ }^{-1}\right)$ and $\mathrm{CoCl}_{2} * 6 \mathrm{H}_{2} \mathrm{O}\left(0.124 \mathrm{mg} \mathrm{Co} \mathrm{L}{ }^{-1}\right)$.
} 
Since the leachate used in this study has low $\mathrm{BOD}_{5} / \mathrm{N}$ ratio, after approximately two months of operation, sodium acetate was also added with the leachate to the anoxic vessel in order to support the denitrification process. The amount of sodium acetate was provided to sustain the denitrification process.

\subsection{Short-term filtration experiments}

Short-term filtration experiment is a simple way to evaluate the performance of the coarse meshes used to develop DM (Li et al., 2012). These experiments were performed in a separate filtration system according to the procedure previously described in Saleem et al. (2017). Briefly, filtration was performed under a constant transmembrane pressure (TMP) of $3.43 \mathrm{kPa}$ provided by the hydrostatic water head maintained above the filtration module connected to a $5 \mathrm{~L}$ stirring tank by a peristaltic pump (Fig. 1b). Filtration fluxes were estimated by measuring the time required to collect a known volume of permeate.

Short-term gravity driven filtration experiments were carried out with 200,85 and $10 \mu \mathrm{m}$ meshes. New meshes were used in the filtration module. The experiments were carried out with the initial inoculum and with the sludge sampled from the aeration tank after 67 days of continuous bioreactor operation (bulk sludge). TSS and VSS concentration inside the bioreactor on $67^{\text {th }}$ day of the continuous bioreactor operation was 7.4 and $4.3 \mathrm{~g} \mathrm{~L}^{-1}$ respectively.

Only for the experiments with bulk sludge, the filtration fluxes were increased to approximately $100 \mathrm{~L} \mathrm{~m}^{-2} \mathrm{~h}^{-1}$ by means of a peristaltic pump (Watson Marlow 505U) when the fluxes reduced to less than $5 \%$ of the initial values.

\subsection{Dynamic membrane operation and cleaning}


Periodical cleaning of the excessively fouled DM layer was performed at the same time for all meshes when the TMP values were higher than $20 \mathrm{kPa}$ or the fluxes were lower than $2 \mathrm{~L} \mathrm{~m}^{-2}$ $\mathrm{h}^{-1}$ for any of the mesh under investigation (set as the lower limit for this study). The meshes were cleaned in situ (i.e. inside the aerobic bioreactor) with the help of a brush.

Since the formation of DM layer after every cleaning operation could greatly compromised the effluent quality in terms of suspended solids removal (Alibardi et al., 2014; 2016), after every cleaning operation, a constant hydrostatic water head of $1.7 \mathrm{kPa}$ was applied to the filtration module to establish high initial filtration fluxes in order to expedite the process of DM formation (Saleem et al., 2016). After the development of DM layer, characterised by the production of a "clear" permeate (visual inspection), constant flux filtration operation (to maintain the design HRT) was resumed. The permeates collected during this interval were returned to the bioreactor. A similar recirculation strategy was also proposed by Ersahin et al. (2012), Alavi Moghaddam et al. (2002) and Fan and Huang (2002) for the start-up of DMs systems.

\subsection{Analytical Method and Measurements}

Total suspended solids (TSS), volatile suspended solids (VSS), ammonium, nitrates, nitrites nitrogen, total phosphorous, 5-day biochemical oxygen demand $\left(\mathrm{BOD}_{5}\right)$, were measured according to standard methods (APHA, AWWA, WEF 2012). Organics matter and alkalinity were estimated measuring the total carbon (TC) and total organic carbon (TOC) by using Shimadzu TOC-V $V_{\text {CSN }}$ analyser. Inorganic carbon (IC) was calculated as difference between TC and TOC.

The concentrations of free ammonia (FA) and free nitrous acid (FNA) were estimated according to Anthonisen et al. (1976). 
Transmembrane pressure (TMP) was measured separately for each DM by using an electronic pressure gauge (COMARK C9505/IS, Pressure Meter, 0-30 PSI). Darcy's equation was used to estimate total DM resistance as follows ( $\mathrm{Li}$ et al., 2012):

$R=\frac{\Delta P}{\mu \cdot J}$

Where $J$ is the permeate flux, $\Delta P$ is TMP across the membrane, $\mu$ is the viscosity of the permeate (assumed of clean water), and $R$ is total membrane resistance.

Dissolved oxygen (DO) concentration inside the bioreactors was monitored by using a DO meter (HANNA HI 9147). Effluent turbidity and $\mathrm{pH}$ were measured using a turbidimeter (HACH 2100 P ISO TURBIDIMETER) and a pH-meter (Crison GLP 22), respectively. Average daily fluxes from the three DM modules were estimated by dividing the volume of the filtrate collected from each filtration module by the filtration area of each module.

\section{Results and Discussion}

\subsection{Dynamic membrane behaviour}

Filtration was started up applying high fluxes in order to speed up the formation of the cake layer on the mesh supports (Saleem et al., 2016). Effluent quality improved rapidly, indicating a quick formation of DM for all meshes and confirming previous results obtained under batch and continuous conditions (Alibardi et al., 2016; Saleem et al., 2017).

The TMP of the different meshes showed similar trends characterised by a typical progressive increase in value during operational filtration (Fig. 2). However, the behaviour of these trends showed a significant change during the study (Fig. 2). For the first 25-30 d, a slow and gradual rise in TMP was observed, according to the local flux theory proposed for conventional membranes (Cho and Fane, 2002). The first week of operation was characterised 
by very low and stable TMP of approximately 1-2 kPa for all meshes, irrespective of the considerable difference in porosities. Afterwards, TMP values gradually and almost steadily increased up to approximately $60 \mathrm{kPa}$ in about 20 days. Owing to the high TMP, the meshes were cleaned following the procedures described in Section 2.4. Thereafter, contrariwise to the first 30 days of operation, the TMP trends were characterised by sharp and fast increases after every cleaning procedure with different maximum values for each mesh pore size. The result obtained over the first 30 days of operation confirms a previous study (Saleem et al., 2017) which demonstrated that the mesh pore size does not significantly affect the filtration flux (Fig. 2). However, after the first 30 days of operation (corresponding to the first filtration period ending with mesh cleaning), the mesh with larger pore-size showed the lowest maximum TMP values when reaching the minimum flux value of $2 \mathrm{~L} \mathrm{~m}^{-2} \mathrm{~h}^{-1}$ (Fig. 2). This suggests that a lower resistance (Fig. 3) was obtained when DM developed on larger pore size. It is of note that the maximum TMP achieved during each filtration cycle (where a filtration cycle can be identified between two cleaning procedures) decreased during the entire duration of the study (Fig. 2). This is particularly evident for the mesh with large pore size (i.e. 200 and $85 \mu \mathrm{m}$ ) where maximum TMP decreased from approximately $60 \mathrm{kPa}$ to less than $20 \mathrm{kPa}$ (Fig. 2a and 2b).

The variation of TMP also affected the filtration fluxes (Fig. 2). Despite the use of a peristaltic pump to control effluent flow, fluxes through each filtration module resulted variable and the observed fluxes were in general higher for larger mesh pore sizes. Due to the very variable $J$, HRT of the system also showed a fluctuating profile with an average value of $20 \pm 9$ days.

A variation of the characteristics of the DM can be highlighted also by the trends of the membrane resistance $(R)$ as calculated by equation 1 (Fig. 3). During the first filtration cycle of approximately 30 days of operation, DM resistance increased gradually from 
approximately $1.0 \times 10^{12}$ to $1.0 \times 10^{14} \mathrm{~m}^{-1}$ for all the meshes under investigation, without large differences among them (Fig. 3). Results suggest that the resistance of the DM was the main contributor of the total resistance of the filtration module, as the intrinsic $R$ of all the meshes measured using tap water was of the order of $1 \times 10^{9} \mathrm{~m}^{-1}$ (Table 1 ).

The behaviour of DM $R$ changed after the first 30 days of operation, showing a much faster build-up at any filtration cycle (Fig. 3). This observation confirms what observed also for TMP, despite $J$ resulted variable. The $R$ measured immediately after every cleaning procedure was always higher than the values measured during the first filtration cycle. This result indicates either that the cleaning process was not able to completely remove the cake layer from the mesh or that the sludge characteristics changed over the experimental study with a measurable impact on DM formation. Moreover, the initial resistance increased with decreasing mesh pore size (Fig. 3).

The change of the characteristics of the sludge and the impact on DM formation is also evident from the measured effluent turbidity (Fig. 3). Very low effluent turbidity values were measured over the first filtration cycle (with values less than 5 NTU), for all the three meshes, demonstrating an excellent solid rejection of the DM, regardless of the difference in mesh size. Despite TMP greatly increased during the first filtration cycle (Fig. 2), effluent turbidity remained almost stable (Fig. 3) confirming the formation of a stable cake layer over the mesh independently, once more, of the pore size. After the first cleaning procedure, the effluent turbidity increased and remained above the low values measured during the first 30 days for the rest of the experimental period (Fig. 3). The related mean turbidity values for 200, 85 and $10 \mu \mathrm{m}$ meshes were $2126 \pm 253,615 \pm 81$ and $37 \pm 20 \mathrm{NTU}$, respectively. As a result, the different DM showed different suspended solid rejection. The DM developed over the mesh of $10 \mu \mathrm{m}$ exhibited very high suspended solids rejection which was always above $95 \%$, while 
the meshes with openings of 85 and $200 \mu \mathrm{m}$ achieved mean solid rejection of approximately 85 and $55 \%$, respectively (data not shown).

In order to find a trade-off between high filtration fluxes observed for 200 and $85 \mu \mathrm{m}$ meshes and high effluent quality observed for $10 \mu \mathrm{m}$ mesh, it was decided to evaluate the performance of $52 \mu \mathrm{m}$ mesh by starting on day 104 of the continuous bioreactor operation. The results showed that the solids rejection performance of $52 \mu \mathrm{m}$ mesh was comparable to that of $10 \mu \mathrm{m}$ in terms of effluent turbidity (Fig. $3 \mathrm{c}$ and $3 \mathrm{~d}$ ). Furthermore, the average filtration fluxes of the DM developed on the mesh with openings of $52 \mu \mathrm{m}$ was higher than those obtained for $10 \mu \mathrm{m}$ mesh and was rather comparable to 200 and $85 \mu \mathrm{m}$ meshes (Fig. 2). The difference in behaviour of the DMs developed over the different meshes between the first filtration cycle (first 30 days) and the cycles during the following three months of operation could be due to two reasons. On the one hand, the cleaning procedures based on brushing, could have been not effective in completely removing the material deposited over the mesh. On the other hand, the applied operating conditions could have changed the sludge characteristic, increasing its fouling propensity. Li et al. (2016) observed by scanning electron microscopy that a significant amount of fouling material remained deeply entrapped inside the mesh of an anaerobic bioreactor, even after intense water flushing and scraping. It is also well documented that the operating conditions of MBR or DMBR affects sludge filtration performance (e.g. Ersahin et al., 2017; Sabia et al., 2013). In addition, the high fouling propensity of landfill leachate, as observed in conventional membrane bioreactor (Ahmed and Lan, 2012), could have changed filtration characteristics of the aerobic/anoxic sludge developed in the experimental bench-scale plant. A previous study on the evaluation of DM development (Saleem et al., 2017) indicated that mesh pore size does not affect DM development, similarly to the results of the first filtration cycle in this research study. It is of note that the results in Saleem et at., 2017 were obtained 
in short term experiments with an anaerobic sludge. On the contrary, other authors (Wu et al., 2003) reported that large mesh pore size favours high filtration fluxes under similar conditions of applied TMP and this observation is in agreement with the second phase of the present research study. The diversity of results between the two phases of the dynamic MBR treating landfill leachate suggests that the operating condition and/or the feed and sludge characteristics influence the development of the cake layer composing the DM and thus its filtration characteristics. As a consequence of this, a proper selection the mesh pore size could facilitate the filtration performance of the DM in particular for those cases where excessive amount of organic foulants (humic and fulvic substances, largely present in stabilized LFL) would have contributed towards much faster DM fouling in the later stage of bioreactor operation (Ahmed and Lan, 2012).

\subsection{Short-term filtration experiments}

During the short-term filtration tests under gravity driven filtration, the inoculum showed flux reduction to less than $10 \%$ of the initial values in 30 minutes (Fig. 4). On the contrary, when the sludge collected from the aerobic tank after more than two months of leachate treatment was used, fluxes reduced to less than $5 \%$ of their initial values within 10 to $15 \mathrm{~min}$ demonstrating a much higher fouling propensity of the bulk sludge than the inoculum (Fig. 4). As a result, the fluxes measured filtering the inoculum were of approximately 10 time higher than those obtained by using the bulk sludge from the reactor if compared after approximately the same filtration time. The much higher fouling propensity of the bulk sludge if compared with the inoculum, can also be evinced in the filtration resistance (Fig. 4).

Since the fluxes reduced very quickly to values well below the $5 \%$ of the initial flux when using the bulk sludge, the fluxes were increased (using a peristaltic pump) to constant values of approximately $100 \mathrm{~L} \mathrm{~m}^{-2} \mathrm{~h}^{-1}$. This operation was carried out in order to assess the 
behaviour of the DM filtration under constant flux as typical condition for MBRs operation. The constant flux filtration caused a slight decrease of filtration resistance for 200 and 85 meshes which was however quickly followed by an increase (Fig. 4). The initial decrease of the filtration resistance for 200 and $85 \mu \mathrm{m}$ meshes suggests the initial formation of a weak DM structure under gravity driven filtration, that was not resistant to the increased flux and the resulting TMP (Fig. 4). Alibardi et al. (2014) have reported a similar observation, during flux-step experiment performed to assess the strength of DM formed under anaerobic conditions treating synthetic wastewater. These results suggest that larger mesh pore sizes form unstable DM which can be easily destabilised with sudden increases of flux. The different behaviour of the bulk sludge if compared with inoculum is also well evident in the turbidity measured in the short-term experiments. During the filtration tests of the inoculum, effluent turbidity reduced to values lower than 10 NTU in 5-10 min, with no particular differences among the three meshes (Fig. 4). When the bulk sludge was used, turbidity remained above 400 NTU although the much lower fluxes and higher resistance. Under constant flux condition, turbidity values increased markedly for 85 and $200 \mu \mathrm{m}$ mesh (Fig. 4) and effluent quality deteriorated due to the loss of loosely bounded particles at high TMP (Fig. 4). In contrast, the continuous deposition of materials on the $10 \mu \mathrm{m}$ mesh formed a DM which was more resistant to much higher TMP values, averaging around $50 \mathrm{kPa}$ (Fig. 4), resulting in an improved effluent quality (Fig. 4).

These results suggest that the cake layer formed by the bulk sludge has a higher propensity to fouling, a more unstable structure and cannot effectively reject solids, if compared to performance obtained from inoculum sludge. The results also indicate that the operation of a DM treating landfill leachate causes a significant deterioration of biofilm on the mesh, at least for its filtration characteristics. The use of large mesh openings seems beneficial on the basis of higher filtration flux and lower operating TMP values for 200 and $85 \mu \mathrm{m}$ meshes than 
those measured for $10 \mu \mathrm{m}$ mesh (Fig. 4); however, such advantages were associated with highly deteriorated effluent quality due to loss of biomass in the effluent. Therefore, these results demonstrate that the behaviour of the DM is affected by the characteristics of the filtered sludge and by the operating conditions applied (i.e. flux and TMP).

\subsection{Landfill leachate treatment}

Dissolved oxygen concentration of the aerobic vessel was always maintained above $1.0 \mathrm{mg} \mathrm{L}$

${ }^{1}$ (data not shown) during the entire bioreactor operation to sustain nitrification. The $\mathrm{pH}$ value of aerobic bioreactor varied between 6.4 and 8.9 (Figure S1 supplementary material).

The bioreactor exhibited moderate TOC removal performance due to the recalcitrant nature of the organics in the leachate. The average TOC removal recorded after 20 days of continuous bioreactor operation was $58 \pm 1.4 \%$ (Figure 6). Moderate organic removals from leachate collected in old landfill are usually observed applying conventional biological processes (e.g. Spagni et al., 2007). In addition, Ahmd and Lan, (2012) reported that conventional MBRs treating stabilised LFL achieve COD removal efficiencies ranging from 54-78\%, similarly to the results of this study. Galleguillos et al. (2011) evaluated the performance of a pilot MBR with a microfiltration membrane in treating stabilised LFL. The system exhibited high BOD and ammonia removal of $94 \%$ and $98 \%$ respectively; however, COD removal was rather low (approx. 40\%) due to the high concentration of recalcitrant organics, confirming the results obtained in this study using a DM bioreactor.

$\mathrm{NH}_{4}{ }^{+}-\mathrm{N}$ oxidation showed a fluctuating trend throughout the study, ranging from 70 to $99 \%$, and despite the high influent $\mathrm{NH}_{4}{ }^{+}-\mathrm{N}$ concentration $\left(1073-1767 \mathrm{mgN} \mathrm{L}^{-1}\right)$, the average $\mathrm{NH}_{4}{ }^{+}-$ $\mathrm{N}$ oxidation was of $84 \pm 1.4 \%$ (Figure $6 \mathrm{~b}$ ). Although the system exhibited high $\mathrm{NH}_{4}{ }^{+}-\mathrm{N}$ oxidation, the biological nitrification process was incomplete and $\mathrm{NO}_{2}{ }^{-} \mathrm{N}$ was the main product of ammonia oxidation (Figure 6b). Along with the increase in influent $\mathrm{NH}_{4}{ }^{+}-\mathrm{N}$ 
concentration towards the end of the experimental phase, a progressive increase in effluent $\mathrm{NO}_{2}{ }^{-}-\mathrm{N}$ concentration was observed, reaching $\mathrm{NO}_{2}{ }^{-}-\mathrm{N}$ values as high as $1062 \mathrm{mg} \mathrm{L}^{-1}$ (Figure 7a). As a consequence of incomplete nitrification, the effluent $\mathrm{NO}_{3}{ }^{-}-\mathrm{N}$ concentration always remained below $160 \mathrm{mgN} \mathrm{L}^{-1}$ (Fig. 6) with average concentration of $86 \pm 6 \mathrm{mgN} \mathrm{L}^{-1}$, showing a limited activity of nitrite oxidising bacteria (NOB).

The severe inhibition of NOB activity can be explained by considering the free ammonia (FA) and free nitrous acid (FNA) concentrations inside the bioreactor (Fig. 7). Their concentrations were above the minimum threshold proved to be toxic for NOB. Anthonisen et al. (1976) reported FA and FNA inhibitory concentrations for NOB bacteria ranging from 0.1 to 150 $\mathrm{mgN} \mathrm{L}^{-1}$ and 0.2 to $2.8 \mathrm{mgN} \mathrm{L}^{-1}$, respectively. Similar inhibitory concentrations have also been confirmed by other authors (Kim et al., 2006; Zhou et al., 2011). Figure 7 shows that inhibition of NOB was triggered by FA concentrations since this compound was mostly above the highest toxicity limit (according to Anthonisen et al., 1976) while FNA was only occasionally higher than the toxicity concentration.

It should also be highlighted that the addition of external carbon to support denitrification could have affected the nitrification activity: Remmas et al. (2016) have recently observed a significant nitrification inhibition when glycerol was added to MBR to sustain denitrification. Although acetate was used in this study instead of glycerol to support nitrogen removal, the addition of external organic material could have affected the microbial community including the specific abundance of nitrifying populations (Remmas et al., 2016).

Even though denitrification via the nitrite route could have offered considerable cost savings in terms of organics and aeration requirements (Spagni and Marsili-Libelli, 2010), the denitrification performance and consequently the total nitrogen removal were rather poor (Fig. 6). Average total nitrogen removal after 20 days of continuous bioreactor operation and before the addition of supplemental organics was only $25 \pm 3 \%$. Moreover, the gradual addition 
of external organics did not bring significant improvement in the denitrification performance (Fig. 6). Furthermore, it can also be inferred that the contribution of heterotrophic denitrification in total TOC removal was very limited and a large fraction of TOC was removed in the aerobic tank instead of anoxic one (data not shown).

Zhou et al, (2011) summarised the results of several studies done on determining the toxicity threshold of FNA concentration on denitrification activity. Depending upon the microbial community structure and operating conditions ( $\mathrm{pH}$, temperature, etc.), FNA concentration as low as $0.01-0.025 \mathrm{mgHNO}_{2}-\mathrm{N} \mathrm{L}^{-1}$ can initiate inhibition (up to $40 \%$ ) while concentration up to $0.2 \mathrm{mgHNO}_{2}-\mathrm{N} \mathrm{L}^{-1}$ was proved to be extremely toxic on denitrification activity. In this study, the observed FNA concentration in the anoxic tank ranged from 0.001 to 0.079 $\mathrm{mgHNO}_{2}-\mathrm{N} \mathrm{L}^{-1}$ and averaging around $0.011 \mathrm{mgHNO}_{2}-\mathrm{N} \mathrm{L}^{-1}$ that might have contributed to the poor denitrification activity of the system (Fig. 6).

\section{Conclusions}

This study showed the possibility of using DM developed over nylon meshes $(10,52,85$ and $200 \mu \mathrm{m})$ in a two-stage anoxic/aerobic bioreactor for the treatment of stabilised LFL.

The results demonstrated the change of the filterability characteristics of the bulk sludge due to the applied operating conditions and to the use of stabilised LFL. As a consequence, severe DM fouling was observed, which was characterised by very sharp increase in TMP. DM solids rejection was also deteriorated and the effect of mesh porosity on solid-liquid separation was heightened. Effective solids rejection was achieved with the mesh with the smallest openings tested in this study of $10 \mu \mathrm{m}$, though at low permeate fluxes (approximately of $5 \mathrm{~L} \mathrm{~m}^{-2} \mathrm{~h}^{-1}$ ). In this regard, among the four meshes tested in this study, $52 \mu \mathrm{m}$ mesh showed to be a reasonable compromise in terms effluent turbidity and achievable operating fluxes. 
The bioreactor achieved organics removal similar to values reported in literature for conventional MBR systems. Even though bioreactor exhibited high ammonia oxidation, the increased concentrations of free ammonia (FA) and free nitrous acid (FNA) inside the system severely affected the nitrification and denitrification performance that resulted in high nitrite accumulation.

\section{Acknowledgments}

Mubashir Saleem gratefully acknowledges the financial support from Fondazione Cassa di Risparmio di Padova e Rovigo (CARIPARO).

\section{References}

1. Ahmed, F.N., Lan, C.Q., 2012. Treatment of LFL using membrane bioreactors: A review. Desalination 287, 41-54. https://doi.org/10.1016/j.desal.2011.12.012

2. Alavi Moghaddam, M. R., Satoh, H., Mino, T., 2002. Performance of coarse pore filtration activated sludge system. Water Sci. Technol. 46, 71-76.

3. Alibardi, L., Cossu, R., Saleem, M., Spagni, A., 2014. Development and permeability of a dynamic membrane for anaerobic wastewater treatment. Bioresource Technol. 161, 236-244. https://doi.org/10.1016/j.biortech.2014.03.045

4. Alibardi, L., Bernava, N., Cossu, R., Spagni, A., 2016. Anaerobic dynamic membrane bioreactor for wastewater treatment at ambient temperature. Chem. Eng. J. 284, 130-138. https://doi.org/10.1016/j.cej.2015.08.111

5. Alvarez-Vazquez, E., Jefferson, B., Judd, S.J., 2004. Membrane bioreactors vs conventional biological treatment of landfill leachate: a brief review. J. Chem. Technol. Biotechnol. 79, 10431049. https://doi.org/10.1002/jctb.1072

6. Anthonisen, A.C., Loehr, R.C., Prakasam, T.B., Srinath, E.G., 1976. Inhibition of nitrification by ammonia and nitrous acid. J. Water Pollut. Control Fed. 48, 835-52.

7. APHA, AWWA, WEF. 2012. Standard Methods for examination of water and wastewater. 22nd ed. Washington: American Public Health Association, American Water Works Association, Water Environment Federation, 1360 pp.

8. Brennan, R.B., Clifford, E., Devroedt, C., Morrison, L., Healy, M.G., 2017. Treatment of landfill leachate in municipal wastewater treatment plants and impacts of effluent ammonium concentrations. J. Environ. Manage. 188, 64-72. https://doi.org/10.1016/j.jenvman.2016.11.055 
9. Cho, B.D., Fane, A.G., 2002. Fouling transients in nominally sub-critical flux operation of a membrane bioreactor. J. Membrane Sci. 209, 391-403. https://doi.org/10.1016/S03767388(02)00321-6

10.Ersahin, M.E., Ozgun, H., Dereli, R.K., Ozturk, I., Roest, K., van Lier, J.B., 2012. A review on dynamic membrane filtration: Materials, applications and future perspectives. Bioresource Technol. 122, 196-206. https://doi.org/10.1016/j.biortech.2012.03.086

11.Ersahin, M.E., Gimenez, J.B., Ozgun, H., Tao, Y., Spanjers, H., van Lier, J.B., 2016. Gas-lift anaerobic dynamic membrane bioreactors for high strength synthetic wastewater treatment: Effect of biogas sparging velocity and HRT on treatment performance. Chem. Eng. J. 305, 46-53. https://doi.org/10.1016/j.cej.2016.02.003

12.Ersahin M.E., Tao Y., Ozgun H., Gimenez J.B., Spanjers H., van Lier, J.B., 2017. Impact of anaerobic dynamic membrane bioreactor configuration on treatment and filterability performance. J. Membrane Sci. 526, 387-394. https://doi.org/10.1016/j.memsci.2016.12.057

13.Fan, B., Huang, X., 2002. Characteristics of a self-forming dynamic membrane coupled with a bioreactor for municipal wastewater treatment. Environ. Sci. Technol. 36, 5245-5251. https://doi.org/10.1021/es025789n

14.Fudala-Ksiazek, S., Pierpaoli, M., Kulbat, E., Luczkiewicz, A., 2016. A modern solid waste management strategy - the generation of new by-products. Waste Manage. 49, 516-529. https://doi.org/10.1016/j.wasman.2016.01.022

15.Galleguillos, M., Keffala, C., Vasel, J.-L., 2011. Simulation of a membrane bioreactor pilot treating old landfill leachates with activated sludge model No. 1 and No. 3. Environ. Technol. 32, 19551965. http://dx.doi.org/10.1080/09593330.2011.561878

16.Hashisho, J., El-Fadel, M., 2016. Membrane bioreactor technology for leachate treatment at solid waste landfills. Rev. Environ. Sci. Biotechnol. 15, 441-463. https://doi.org/10.1007/s11157-0169399-5

17.Hu, Y., Wang, X.C., Tian, W., Ngo, H.H., Chen, R., 2016. Towards stable operation of a dynamic membrane bioreactor (DMBR): Operational process, behavior and retention effect of dynamic membrane. J. Membrane Sci. 498, 20-29. https://doi.org/10.1016/j.memsci.2015.10.009

18.Jeison, D., Díaz, I., Van Lier, J.B., 2008. Anaerobic membrane bioreactors: Are membranes really necessary? Electron. J. of Biotechnol. 11. https://doi.org/10.2225/vol11-issue4-fulltext-9

19.Judd, S., 2011. The MBR book : principles and applications of membrane bioreactors for water and wastewater treatment. Butterworth-Heinemann.

20.Kim, D.-J., Lee, D.-I., Keller, J., 2006. Effect of temperature and free ammonia on nitrification and nitrite accumulation in landfill leachate and analysis of its nitrifying bacterial community by FISH. Bioresource Technol. 97, 459-468. https://doi.org/10.1016/j.biortech.2005.03.032 
21.Kiso, Y., Jung, Y.J., Ichinari, T., Park, M., Kitao, T., Nishimura, K., Min, K.S., 2000. Wastewater treatment performance of a filtration bio-reactor equipped with a mesh as a filter material. Water Res. 34, 4143-4150. https://doi.org/10.1016/S0043-1354(00)00201-3

22.Kjeldsen, P., Barlaz, M. A., Rooker, A. P., Baun, A., Ledin, A., \& Christensen, T. H., 2002. Present and long-term composition of MSW landfill leachate: A review. Crit. Rev. Env. Sci. Technol. 32, 297-336. http://dx.doi.org/10.1080/10643380290813462

23.Kulikowska, D., Klimiuk, E., 2008. The effect of landfill age on municipal leachate composition, Bioresource Technol. 99, 5981-5985. https://doi.org/10.1016/j.biortech.2007.10.015

24.Li, W.W., Sheng, G.P., Wang, Y.K., Liu, X.W., Xu, J., Yu, H.Q., 2011. Filtration behaviors and biocake formation mechanism of mesh filters used in membrane bioreactors. Sep. Purif. Technol. 81, 472-479. https://doi.org/10.1016/j.seppur.2011.08.026

25.Li, W.W., Wang, Y.K., Xu, J., Tong, Y.R., Zhao, L., Peng, H., Sheng, G.P., Yu, H.Q., 2012. A dead-end filtration method to rapidly and quantitatively evaluate the fouling resistance of nylon mesh for membrane bioreactors. Sep. Purif. Technol. 89, 107-111. https://doi.org/10.1016/j.seppur.2012.01.019

26.Li N., Hu Y., Lu Y.-Z., Zeng R.J., Sheng G.-P., 2016. In-situ biogas sparging enhances the performance of an anaerobic membrane bioreactor (AnMBR) with mesh filter in low-strength wastewater treatment. Appl. Microbiol. Biotechnol. 100, 6081-6089. https://doi.org/10.1007/s00253-016-7455-2

27.Liu, H., Yang, C., Pu, W., Zhang, J., 2009. Formation mechanism and structure of dynamic membrane in the dynamic membrane bioreactor. Chem. Eng. J. 148, 290-295. https://doi.org/10.1016/j.cej.2008.08.043

28.Mohammad-pajooh, E., Weichgrebe, D., Cuff, G., 2017. Municipal landfill leachate characteristics and feasibility of retrofitting existing treatment systems with deammonification - A full scale survey. J. Environ. Manage. 187, 354-364. https://doi.org/10.1016/j.jenvman.2016.10.061

29.Oloibi V., Chys M., De Wandel S., Demeestere K., Van Hulle S.W.H., 2017. Removal of organic matter and ammonia from landfill leachate through different scenarios: Operational cost evaluation in a full-scale case study of a Flemish landfill. J. Environ. Manage. 203, 774-781. https://doi.org/10.1016/j.jenvman.2016.09.055

30.Remmas N., Melidis P., Katsioupi E., Ntougias S., 2016. Effect of high organic load on amoA and nirS gene diversity of an intermittently aerated and fed membrane bioreactor treating landfill leachate. Bioresource Technol. 220, 557-565. https://doi.org/10.1016/j.biortech.2016.09.009

31.Renou, S., Givaudan, J.G., Poulain, S., Dirassouyan, F., Moulin, P., 2008. Landfill leachate treatment: Review and opportunity. J. Hazard. Mater. 150, 468-493. https://doi.org/10.1016/j.jhazmat.2007.09.077 
32.Sabia, G., Ferraris, M., Spagni, A., 2013. Effect of solid retention time on sludge filterability and biomass activity: long-term experiment on a pilot-scale membrane bioreactor treating municipal wastewater. Chem. Eng. J. 221: 176-184. https://doi.org/10.1016/j.cej.2013.01.094

33.Saleem, M., Alibardi, L., Lavagnolo, M.C., Cossu, R., Spagni, A., 2016. Effect of filtration flux on the development and operation of a dynamic membrane for anaerobic wastewater treatment. J. Environ. Manage. 180, 459-465. https://doi.org/10.1016/j.jenvman.2016.05.054

34.Saleem, M., Alibardi, L., Lavagnolo, M.C., Cossu, R., Spagni, A., 2017. Analysis of fouling development under dynamic membrane filtration operation. Chem. Eng. J. 312, 136-143. https://doi.org/10.1016/j.cej.2016.11.123

35.Spagni, A., Lavagnolo, M.C., Scarpa, C., Vendrame, P., Rizzo, A., Luccarini, L., 2007. Nitrogen removal optimization in a sequencing batch reactor treating sanitary landfill leachate. J. Environ. Sci. Heal. A. 42, 757-765. http://dx.doi.org/10.1080/10934520701304435

36.Spagni, A., Marsili-Libelli, 2010. Artificial intelligence control of a sequencing batch reactor for nitrogen removal via nitrite from landfill leachate. J. Environ. Sci. Heal. A. 45, 1085-1091. http://dx.doi.org/10.1080/10934529.2010.486339

37.Sutzkover-Gutman, I., Hasson, D., Semiat, R., 2010. Humic substances fouling in ultrafiltration processes. Desalination 261, 218-231. https://doi.org/10.1016/j.desal.2010.05.008

38.Wu, Y., Huang, X., Zuo, W., 2003. Effect of mesh pore size on performance of a self-forming dynamic membrane coupled bioreactor for domestic wastewater treatment. 5th International Membrane Science \& Technology Conference, Sydney, Australia, November 10-14.

39.Xie, Z., Wang, Z., Wang, Q., Zhu, C., Wu, Z., 2014. An anaerobic dynamic membrane bioreactor (AnDMBR) for landfill leachate treatment: Performance and microbial community identification. Bioresource Technol. 161, 29-39. https://doi.org/10.1016/j.biortech.2014.03.014

40.Xiong, J., Fu, D., Singh, R.P., Ducoste, J.J., 2016. Structural characteristics and development of the cake layer in a dynamic membrane bioreactor. Sep. Purif. Technol. 167, 88-96. https://doi.org/10.1016/j.seppur.2016.04.040

41.Zhang, X., Wang, Z., Wu, Z., Lu, F., Tong, J., Zang, L., 2010. Formation of dynamic membrane in an anaerobic membrane bioreactor for municipal wastewater treatment. Chem. Eng. J. 165, 175183. https://doi.org/10.1016/j.cej.2010.09.013

42.Zhou, Y., Oehmen, A., Lim, M., Vadivelu, V., Ng, W.J., 2011. The role of nitrite and free nitrous acid (FNA) in wastewater treatment plants. Water Res. 45, 4672-4682. https://doi.org/10.1016/j.watres.2011.06.025 


\section{Table captions}

Table 1. Properties of the meshes used in this study.

Table 2. Average characteristics of the leachate samples. 
Table 1. Properties of the meshes used in this study.

\begin{tabular}{|c|c|c|c|c|c|c|}
\hline $\begin{array}{l}\text { Product } \\
\text { information }\end{array}$ & $\begin{array}{c}\text { Mesh } \\
\text { opening } \\
(\mu \mathrm{m})\end{array}$ & $\begin{array}{l}\text { Open } \\
\text { area } \\
(\%)\end{array}$ & $\begin{array}{l}\text { Mesh } \\
\text { count } \\
\left(\mathrm{cm}^{-1}\right)\end{array}$ & $\begin{array}{c}\text { Thread } \\
\text { diameter } \\
(\mu \mathrm{m})\end{array}$ & $\begin{array}{c}\text { Resistance } \\
\text { (Clean mesh) } \\
\left(\mathrm{m}^{-1}\right)^{(2)}\end{array}$ & $\begin{array}{c}\text { Tap water } \\
\text { permeability } \\
\left(\mathrm{L} \mathrm{m}^{-2} \mathrm{~h}^{-1} \mathrm{kPa}^{-1}\right)^{(3)}\end{array}$ \\
\hline SaatiMil PA $^{(1)} 7$ & 200 & 39 & 31 & 120 & $5.5 \times 10^{9}$ & 1570 \\
\hline SaatiMil PA 15 & 85 & 49 & 81 & 37 & $5.4 \times 10^{9}$ & 1580 \\
\hline Saatifil PA 52/32 & 52 & 32 & 110 & 38 & $5.6 \times 10^{9}$ & 1530 \\
\hline Saatifil PA 10/4 & 10 & 4 & $200 \times 220$ & $30 \times 38$ & $6.5 \times 10^{9}$ & 1330 \\
\hline
\end{tabular}

(1) PA is an acronym for polyamide

(2) Resistance of the mesh measured at TMP of $5 \mathrm{kPa}$

(3) $20{ }^{\circ} \mathrm{C}$ normalised permeability measured at TMP of $5 \mathrm{kPa}$ 
Table 2. Average characteristics of the leachate samples.

\begin{tabular}{lc}
\hline Parameter & Value \\
\hline $\mathrm{BOD}_{5}\left(\mathrm{mgO}_{2} \mathrm{~L}^{-1}\right)$ & 400 \\
\hline $\mathrm{TOC}\left(\mathrm{mgC} \mathrm{L}^{-1}\right)$ & 1300 \\
\hline $\mathrm{TKN}\left(\mathrm{mgN} \mathrm{L}^{-1}\right)$ & 2060 \\
\hline $\mathrm{NH}_{4}^{+}-\mathrm{N}\left(\mathrm{mgN} \mathrm{L}^{-1}\right)$ & 1700 \\
\hline $\mathrm{NO}_{3}^{-}-\mathrm{N}\left(\mathrm{mgN} \mathrm{L}^{-1}\right)$ & $<1$ \\
\hline $\mathrm{NO}_{2}^{-}-\mathrm{N}\left(\mathrm{mgN} \mathrm{L}^{-1}\right)$ & 7.7 \\
\hline Total phosphorus $\left(\mathrm{mgP} \mathrm{L}^{-1}\right)$ & 9.6 \\
\hline $\mathrm{pH}$ & 8.56 \\
\hline $\mathrm{Alkalinity}\left(\mathrm{mg} \mathrm{CaCO}_{3} \mathrm{~L}^{-1}\right)$ & 14600 \\
\hline $\mathrm{Cd}\left(\mu \mathrm{g} \mathrm{L}^{-1}\right)$ & $<10$ \\
\hline $\mathrm{Cr}\left(\mu \mathrm{g} \mathrm{L}^{-1}\right)$ & 753 \\
\hline $\mathrm{Cu}\left(\mu \mathrm{g} \mathrm{L}^{-1}\right)$ & 52 \\
\hline $\mathrm{Fe}\left(\mu \mathrm{g} \mathrm{L}^{-1}\right)$ & 3860 \\
\hline $\mathrm{Mn}\left(\mu \mathrm{g} \mathrm{L}^{-1}\right)$ & 172 \\
\hline $\mathrm{Ni}\left(\mu \mathrm{g} \mathrm{L}^{-1}\right)$ & 148 \\
\hline $\mathrm{Pb}\left(\mu \mathrm{g} \mathrm{L}^{-1}\right)$ & $<10$ \\
\hline $\mathrm{Zn}\left(\mu \mathrm{g} \mathrm{L}^{-1}\right)$ & 112 \\
\hline
\end{tabular}




\section{Figure captions}

Figure 1. Schematic diagrams (a) experimental setup and (b) short-term filtration test set-up Figure 2. Observed filtration flux and TMP profiles for (a) $200 \mu \mathrm{m}$, (b) $85 \mu \mathrm{m}$, (c) $52 \mu \mathrm{m}$ and (d) $10 \mu$.

Figure 3. Dynamic membrane resistance profiles along with effluent turbidity values (a) $200 \mu \mathrm{m}$, (b) $85 \mu \mathrm{m}$, (c) $52 \mu \mathrm{m}$ and (d) $10 \mu \mathrm{m}$

Figure 4. Results of short-term gravity driven filtration tests: flux (a,d) resistance $(b, e)$ and turbidity (c, f) profiles for initial inoculum and for bulk sludge, respectively. Arrows indicate when the peristaltic pump was switched on (bulk sludge only) to increase membrane flux; square, triangle and circle below the arrows are for mesh of 200,85 and $10 \mu \mathrm{m}$, respectively. TMP profile for bulk sludge experiment is inserted in graph (d).

Figure 5. Influent and effluent TOC profiles and TOC removal performance.

Figure 6. (a) influent (INF) and effluent (EFF) ammonia and effluent nitrite and nitrate concentration; (b) ammonia oxidation and nitrogen removal performance

Figure 7. Free ammonia (a) and free nitrous acid (b) concentration and values of toxicity for nitrifying microorganism according to Anthonisen et al. (1976). 

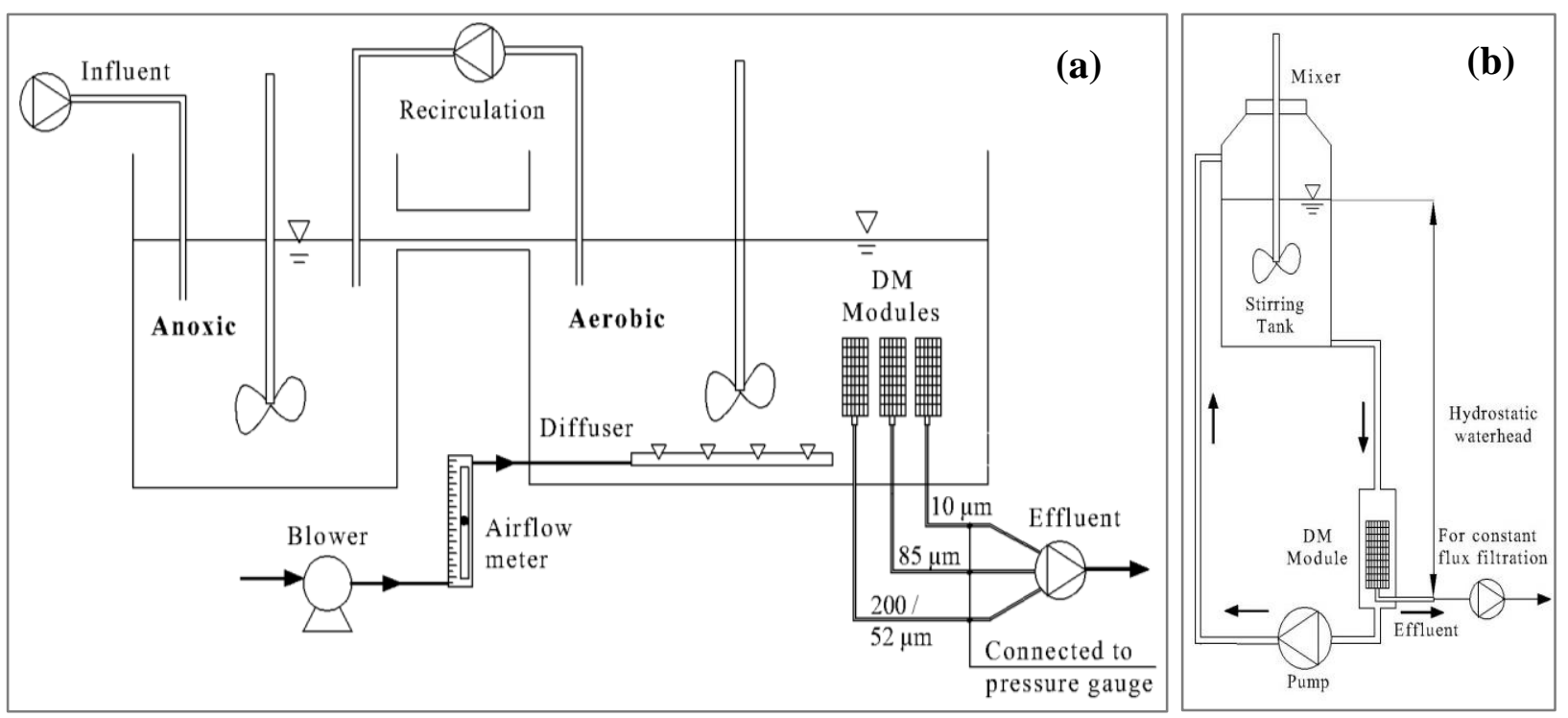

Figure 1. Schematic diagrams (a) experimental setup and (b) short-term filtration test set-up 


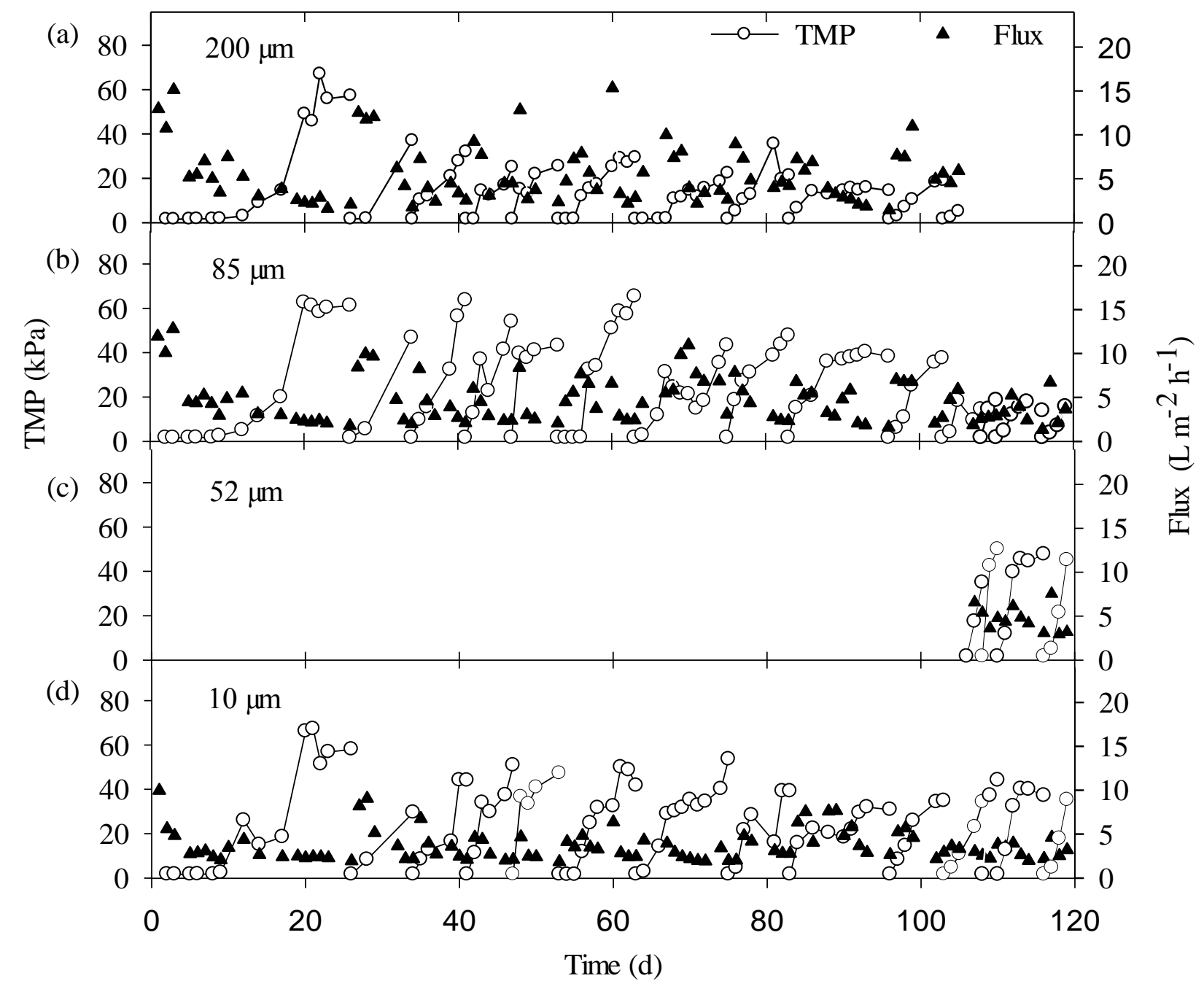

Figure 2. Observed filtration flux and TMP profiles for (a) $200 \mu \mathrm{m}$, (b) $85 \mu \mathrm{m}$, (c) $52 \mu \mathrm{m}$ and (d) $10 \mu$. 


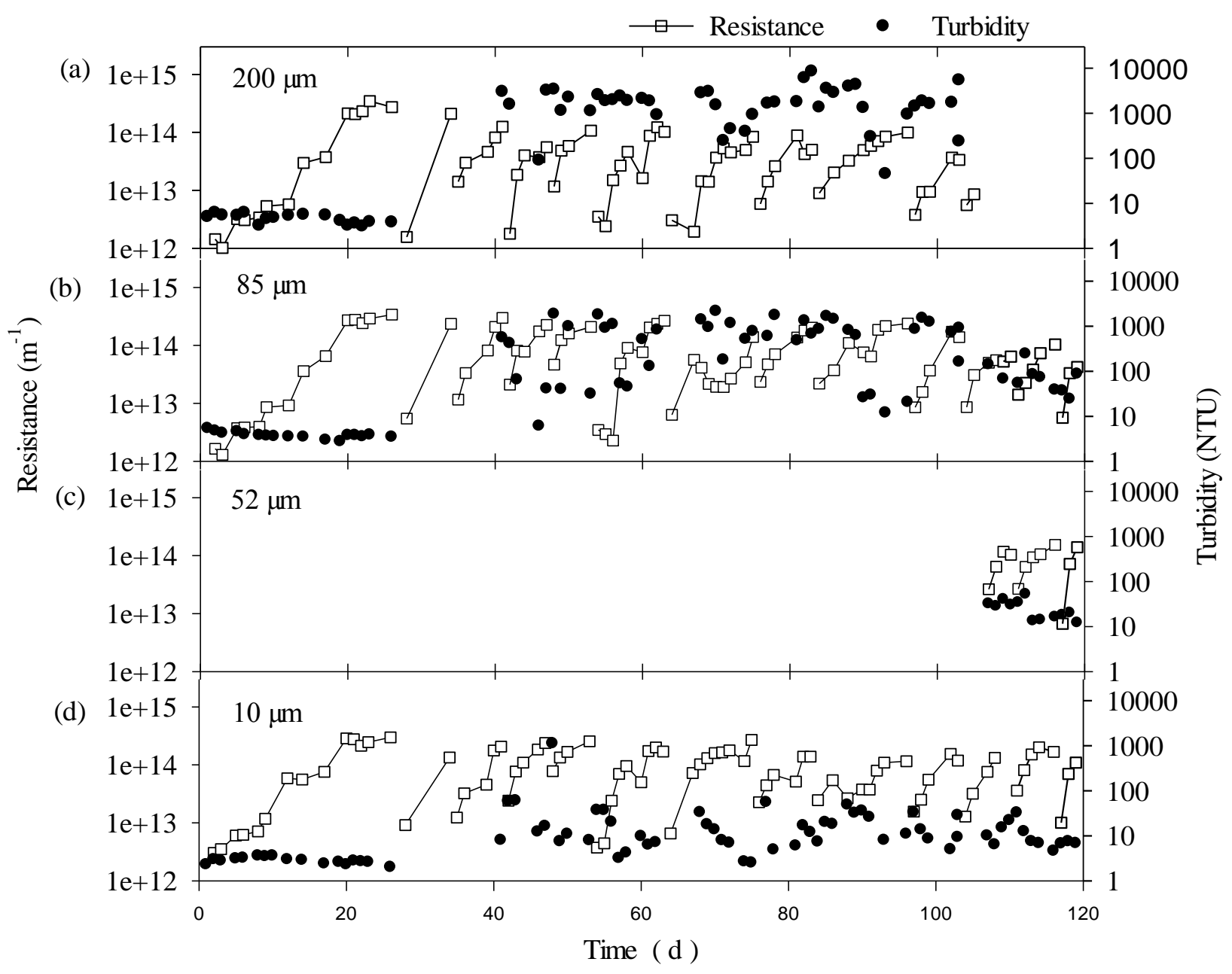

Figure 3. Dynamic membrane resistance profiles along with effluent turbidity values (a) $200 \mu \mathrm{m}$, (b) $85 \mu \mathrm{m}$, (c) $52 \mu \mathrm{m}$ and (d) $10 \mu \mathrm{m}$ 
Inoculum
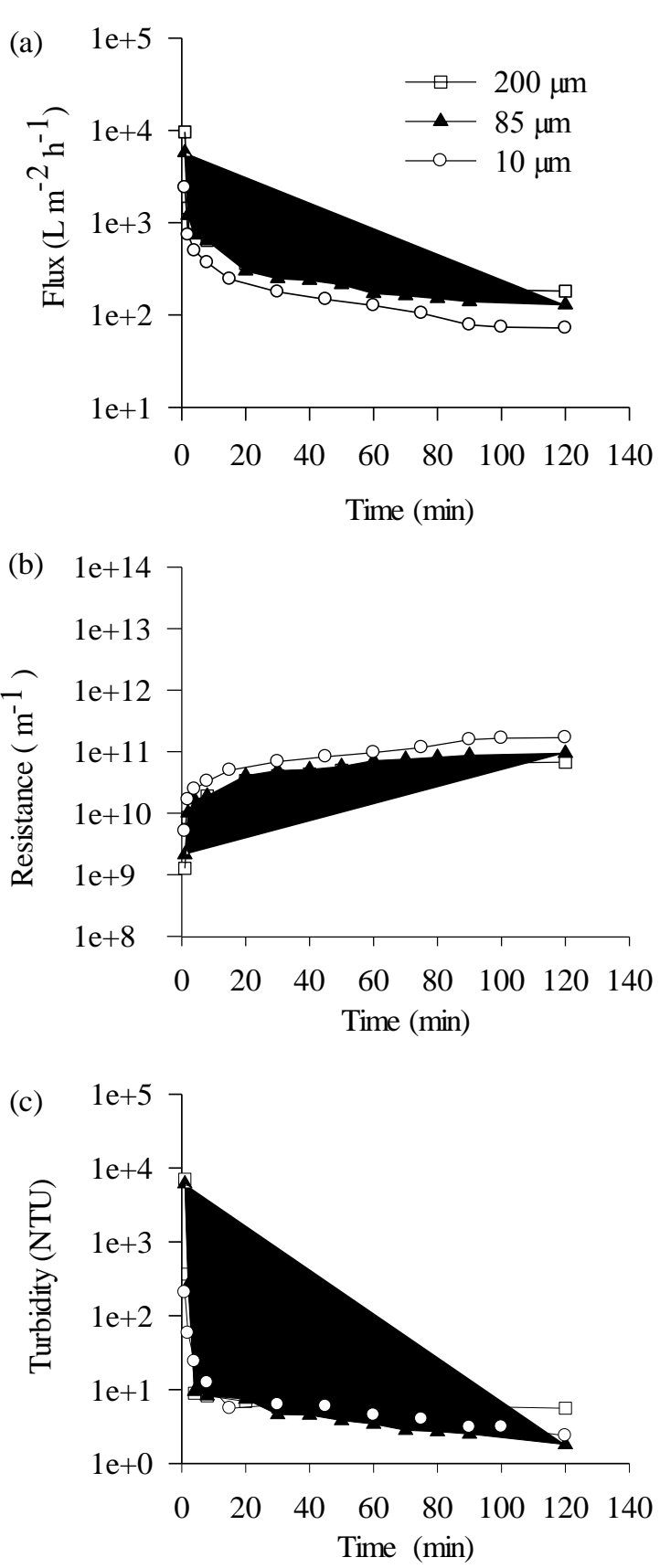

Bulk sludge
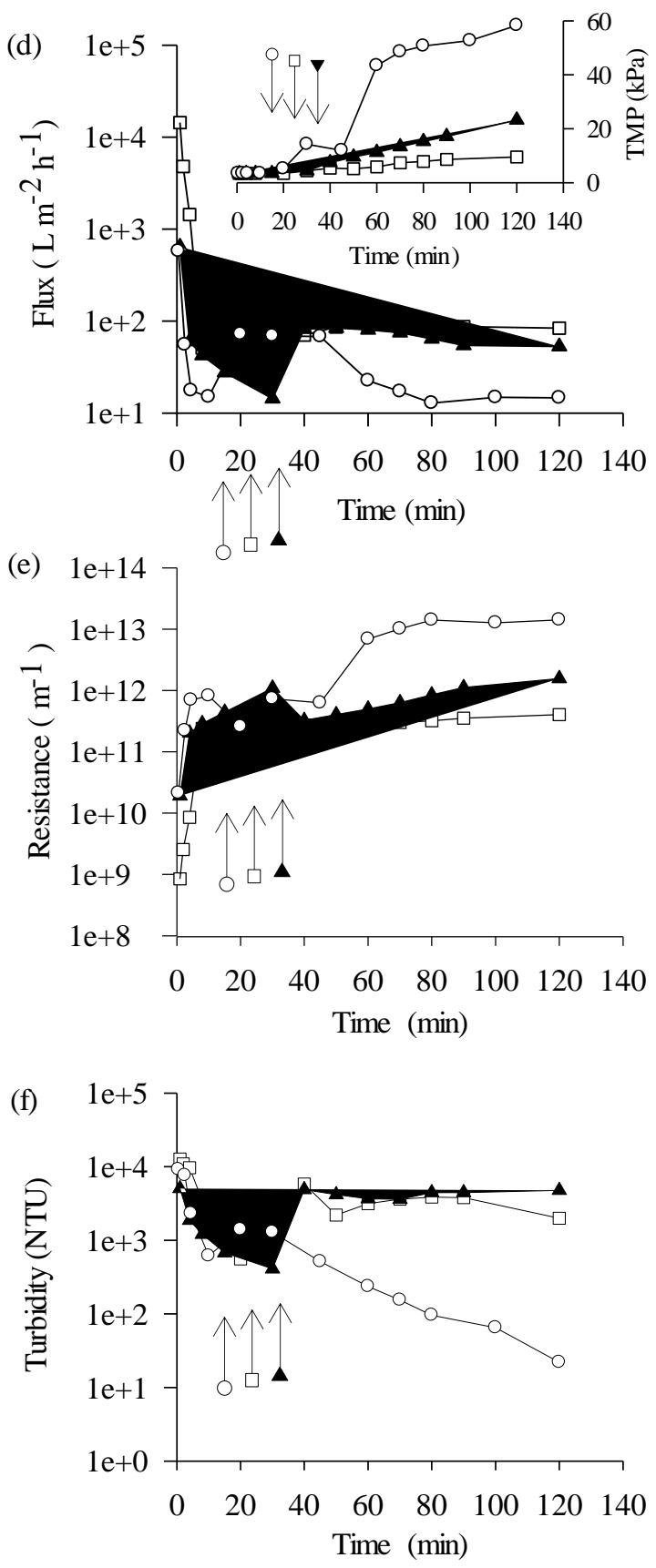

Figure 4. Results of short-term gravity driven filtration tests: flux $(a, d)$ resistance $(b, e)$ and turbidity (c, f) profiles for initial inoculum and for bulk sludge, respectively. Arrows indicate when the peristaltic pump was switched on (bulk sludge only) to increase membrane flux; square, triangle and circle below the arrows are for mesh of 200,85 and $10 \mu \mathrm{m}$, respectively. TMP profile for bulk sludge experiment is inserted in graph (d). 


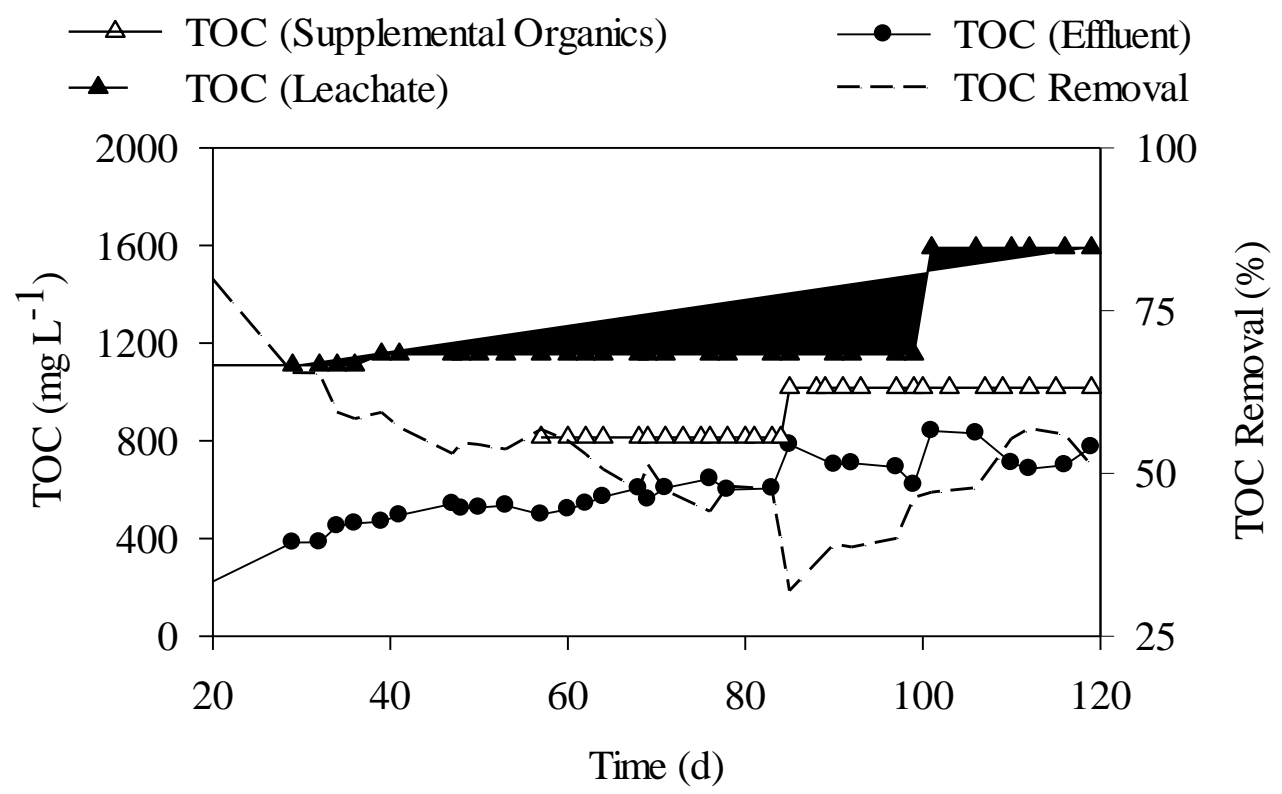

Figure 5. Influent and effluent TOC profiles and TOC removal performance. 


$$
\begin{aligned}
& ---\mathrm{INF} \mathrm{NH} 4^{+}-\mathrm{N} \longrightarrow \mathrm{EFF} \mathrm{NO}_{2}^{-}-\mathrm{N} \longrightarrow \mathrm{N} \text { removal } \\
& \multimap \mathrm{EFF} \mathrm{NH}_{4}{ }^{+}-\mathrm{N} \longrightarrow \mathrm{EFF} \mathrm{NO}_{3}^{-}-\mathrm{N} \longrightarrow \mathrm{NH}^{+}-\mathrm{N} \text { oxidation }
\end{aligned}
$$

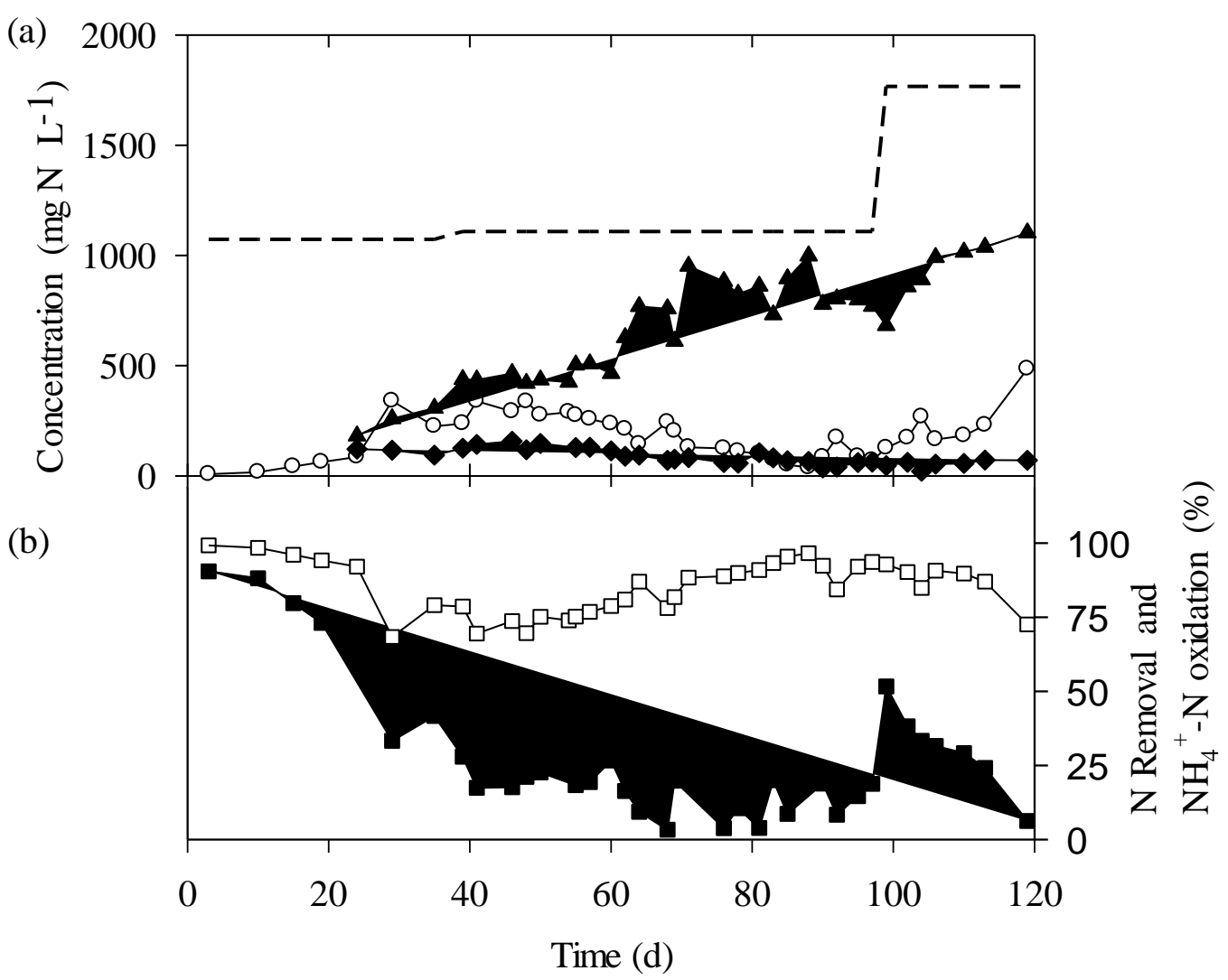

Figure 6. (a) influent (INF) and effluent (EFF) ammonia and effluent nitrite and nitrate concentration; (b) ammonia oxidation and nitrogen removal performance 


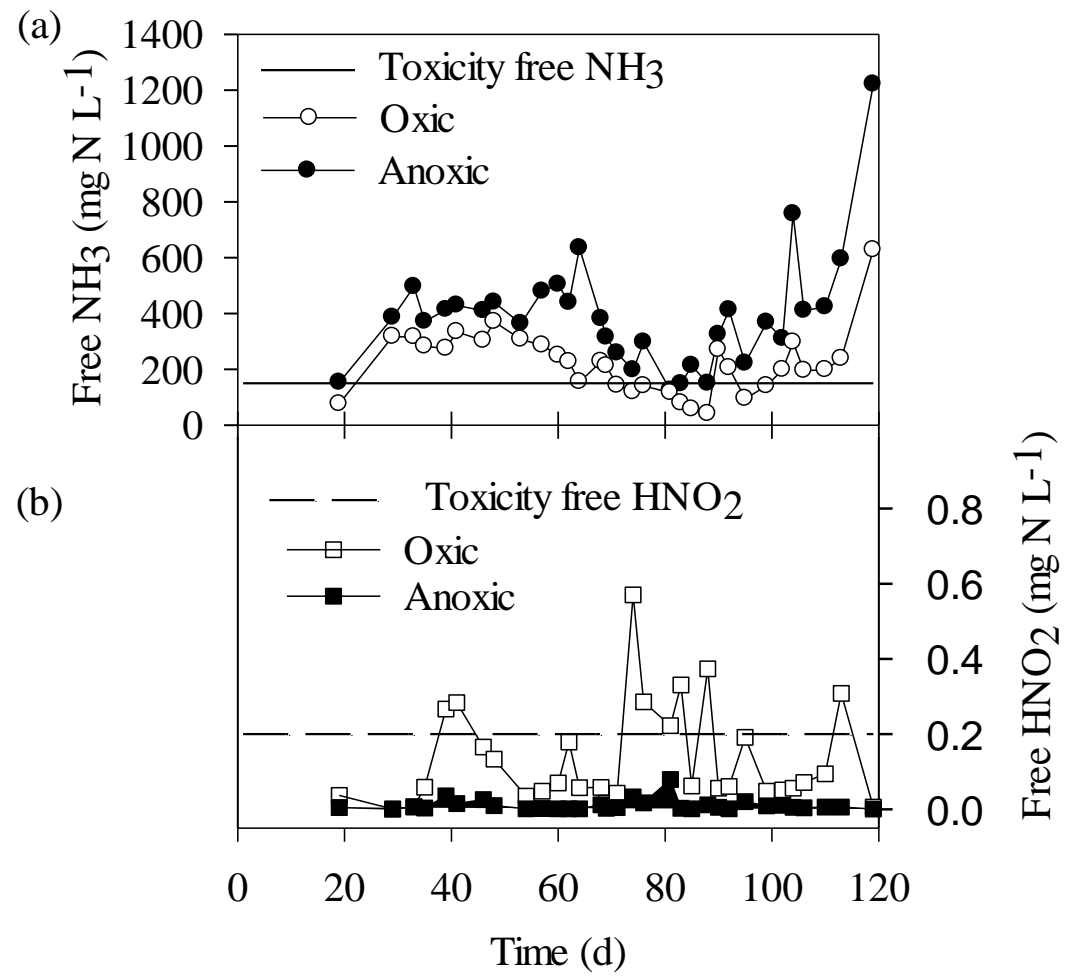

Figure 7. Free ammonia (a) and free nitrous acid (b) concentration and values of toxicity for nitrifying microorganism according to Anthonisen et al. (1976). 


\section{Supplementary material}

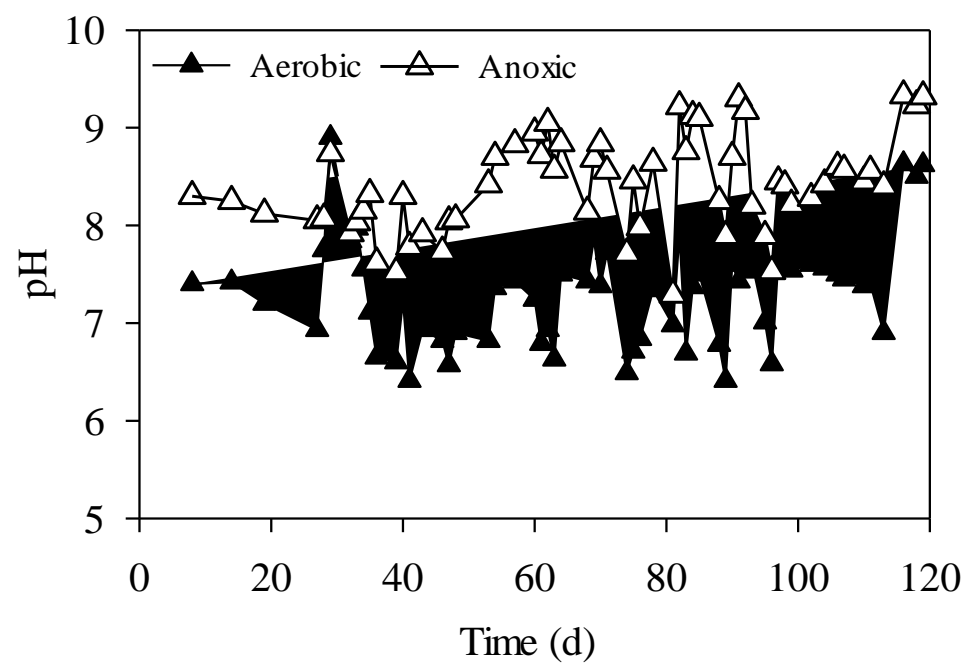

Figure S1. Observed $\mathrm{pH}$ profile inside the aerobic and anoxic tank. 